\title{
WSTĘP. KULTURA SYTUACJI POSTKOLONIALNEJ
}

14 numer „Porównań” przynosi kolejne teksty wygłoszone na międzynarodowej konferencji pt. Kultura sytuacji postkolonialnej, która odbyła się w dniach 6-7 maja 2013 roku w Poznaniu, zorganizowanej przez Zakład Komparatystyki Literackiej i Kulturowej Instytutu Filologii Polskiej UAM, w ramach projektu grantowego ${ }^{1}$. W tomie zgromadzono prace, które $\mathrm{w}$ „bliskim czytaniu” poddają analizie literackiej dyskursy postkolonialne, odnoszące się do współczesnych stosunków z "innymi” i nawiązujące do dawnej lub współczesnej relacji dominowania i upodrzędniania. Autorzy rozpatrują w wybranych utworach literackich różnorodne doświadczenia z okresu zależności: skutki nostalgicznych uwikłań pamięci sytuacji kolonialnej, wątki i postaci związane z kolonialną przeszłością, ironiczne narracje, które ujawniają sprzeczność dwóch poziomów wypowiedzi, w której podmiot podlega kolonizacji, a jednocześnie stara się ją przezwyciężyć, duchowe stany po utracie związku z hegemonem, postkolonialne dysfunkcje skutkujące zakłóceniami w działaniu mechanizmów demokratycznych uszkodzonych przez sytuację kolonialną, itd.

Białoruskie doświadczenie kolonialne zawarte w prozie Artura Klinaua zajmuje Lajosa Pálfaviego, który przygląda się utopijnej wizji państwa rysowanej przez białoruskiego pisarza na wzór koncepcji Miasta Słońca Tommaso Campanelliego. Zmagania $\mathrm{z}$ konsekwencjami postkolonialnej traumy zawarte w literaturze litewskiej rozpatruje Marta Kowerko-Urbańczyk na przykładzie powieści Renaty Šerelytè i Sigitasa Parulskisa, autorów debiutujących po 1991 roku. Autorkę interesuje związek pomiędzy sytuacją postkolonialną niepodległej Litwy i generowaną przez nią niemocą a pozornością przełomu genderowego, dowodzącą „postkolonialnej

1 Projekt badawczy NPRH 12H 110018 80: Dyskurs postkolonialny w Europie Środkowo-Wschodniej 1991-2011: Polska, Wegry, Stowacja, Ukraina. Literatura, eseistyka, stan badań.

Pierwsza grupa tekstów wygłoszonych na konferencji opublikowana została w 13 numerze „Porównań" z 2013 roku. 
schizofrenii" - zjawiska opisywanego przez Mykołę Riabczuka. Imagologiczna refleksja Ryszarda Kupidury skupiona została na sposobach obecności Polaków jako postaci literackich na kartach modernistycznej i postmodernistycznej literatury ukraińskiej. Dokonując porównania tekstów literackich z tak odległych epok, Autor nie pozostaje na poziomie konkluzji o słabej reprezentacji wątków polskich $\mathrm{w}$ tej literaturze, ale koncentruje się przede wszystkim na przeobrażeniach stereotypu bohaterów, które dokonały się w prozie ostatnich lat. Kupidura, tropiąc antykolonialne resentymenty $\mathrm{w}$ wytwarzanych literacko polskich etnoobrazach w prozie ukraińskiej, otwiera jednocześnie dyskusję nad formami relacji międzykulturowych, których obecny kształt wynika z doświadczeń kolonialnych.

Bałkańskie problemy podjęte zostały w trzech artykułach. Tekst Sabiny Giergiel odkrywa kreatywny potencjał nostalgii zawarty w felietonach bośniackiego prozaika Aleksandra Hemona, występującego przeciw wyidealizowanej wizji państwa jugosłowiańskiego. Nostalgia staje się kategorią zdolną do opisu Bośni po rozpadzie, pozwalającą rozpatrywać wartość i znaczenie utraconej wspólnoty. Sylwię Nowak-Bajcar zainteresowała burzliwa recepcja twórczości serbskiego pisarza i eseisty Danila Kiša, w szczególny sposób postkolonialne strategie odczytywania jego twórczości przez serbskich intelektualistów. Problem wyrażania wewnętrznego bałkanizmu (termin Marii Todorovej) Judit Reiman rozpatruje na przykładzie słoweńskiej powieści Gorana Vojnovicia opisującej sytuację postjugosłowiańską widzianą oczyma "czefura” - młodego przesiedleńca z południowych republik Jugosławii do Słowenii.

Węgierskie zmagania $\mathrm{z}$ postkolonialną traumą podjęte zostały $\mathrm{w}$ dwóch tekstach. Kinga Piotrowiak-Junkiert, przyglądając się noweli Mihálya Kornisa pt. Podanie, zwraca uwagę na zjawisko przełamywania stereotypu pisania o Zagładzie w najnowszej literaturze węgierskiej, przywrócenia tematu Zagłady kulturze tego kraju wbrew antysemickim głosom, które odżyły po 1989 roku. Z kolei Csilla Gizińska prezentuje ironiczną, intelektualną refleksję nad sytuacją wspólnoty węgierskiej zawartą w cyklu powieściowym Lajosa Grendela. Tytułowy Absurdystan (Europa Środkowa) postrzegany jest jako region irracjonalny, marginalizujący i pasywny. Prowokacyjne konstatacje Grendela służyć mają, jak wskazuje Autorka, samopoznaniu Węgrów.

Łotewskie problemy czasu transformacji: próbę zmierzenia się z przeszłością i kłopoty ze znalezieniem się $\mathrm{w}$ przestrzeni uwolnionej od zależności z powieści Agnesy Bule, wyczytuje Justyna Prusinowska.

Czeskie, słowackie i polskie rozliczanie się z przeszłością zawarte $\mathrm{w}$ literaturze emigrantów porzucających rodzimy język postawiła w centrum swojego zainteresowania Joanna Czaplińska. Badaczka opisuje fenomen „konwertytów językowych" próbujących oddać doświadczenie życia w totalitaryzmie w podobnych strategiach użycia języka obcego, pozwalającego im zyskać dystans przy opisie doświadczeń przeszłości. 
Polskie postkolonialne uwarunkowania tropi natomiast Natalia Lemann w rodzimych historiach alternatywnych, dowodząc, iż polska specyfika powieści alternatywnej wynika z mentalności postkolonialnej, w której traumatyczne doświadczenia subalterna decydują o sposobach kreowania wyimaginowanej przeszłości. Arkadiusz Kalin, analizując twórczość Andrzeja Stasiuka, podkreśla jego postkolonialną perspektywę przedstawiania Europy Wschodniej opierającej się na podkreślaniu opozycji Wschodu i Zachodu, która ujawnia uwikłanie pisarza w mentalność skolonizowanego. Proza Andrzeja Stasiuka stała się także przedmiotem postkolonialnej refleksji Anne-Marie Monluçon, a w szczególności reakcje ostalgiczne mieszkańców Mołdawii, opisane w prozie podróżniczej Jadąc do Babadag. Sytuację pamięci wielokulturowego współistnienia przedstawioną $\mathrm{w}$ tekstach reportażowych Marina Pollacka i Włodzimierza Pawluczuka analizuje w swoim artykule Zbigniew Kopeć. Problematyka kaszubskiej mniejszości językowej stała się przedmiotem refleksji Daniela Kalinowskiego. Dowodem na odradzanie się po 1989 roku się kaszubskiej tradycji kulturowej, zdaniem Autora, jest aktywność czasopiśmiennictwa kaszubskojęzycznego, stawiającego sobie za cel odbudowę podmiotowości tej grupy etnicznej. Tekst Jerzego Kandziory poprzez przybliżenie kontekstu literackiego i ideologicznego wczesnych zainteresowań cyganologicznych Jerzego Ficowskiego, odnotowanych w korespondencji między Ficowskim a Julianem Tuwimem, uzmysławia funkcjonowanie mniejszości etnicznych w warunkach sytuacji kolonialnej, skutkującej skomplikowanymi relacjami nie tylko z zewnętrznym opresorem, ale także większością, poddaną wraz z nimi praktykom kolonizacyjnym.

Zawarte w tym tomie analizy zróżnicowanych przypadków sytuacji postkolonialnej nie wyczerpują, oczywiście, odpowiedzi na pytanie o skutki społeczne, mentalne i artystyczne wieloletniej zależności, jakiej podlegały narody krajów Europy Środkowo-Wschodniej. Włączają się raczej w namysł nad naszą współczesnością, której kondycję wyznacza także doświadczenie niedawnej kolonialnej przeszłości. Refleksja nad nią prowadzona $\mathrm{z}$ perspektywy postkolonialnej daje szansę na uwolnienie się od jej obezwładniającego ciężaru.

Dobrochna Dabert (Uniwersytet im. Adama Mickiewicza w Poznaniu) 